\title{
TENTATIVE STANDARD TEST METHODS AND PER- CENTAGES OF OIL AND MOISTURE IN HAIR PRESS CLOTHS.
}

\author{
By F. R. McGowan and C. W. Schoffstall.
}

ABSTRACT.

Hair press cloth is used in the oil-pressing industries in the extraction of the oil from the pulpy matter. Hair fibers are more generally used than others on account of the resiliency required. Since the fabric is bought on a weight basis, the moisture and oil which are added to permit efficient manufacturing become important items. This paper outlines means of ascertaining the various contents. The petroleum ether extraction method is used for obtaining the oil content. The results of testing $27 \mathrm{sam}$ ples are given. The standard percentages obtained are as follows: Moisture, II per cent; oil, 5 per cent; water-soluble material, $21 / 2$ per cent.

\section{CONTENTS.}

I. Introduction

Page.

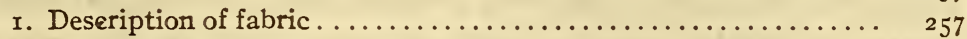

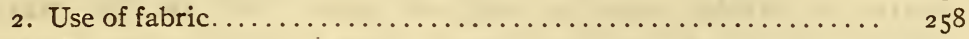

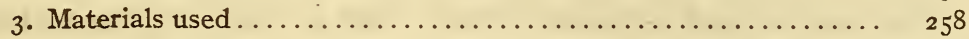

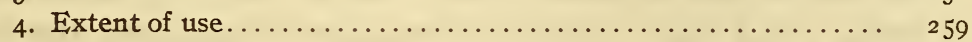

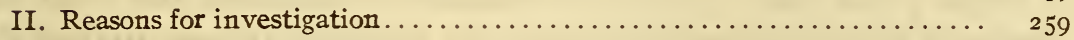

III. Purpose of investigation. . . . . . .

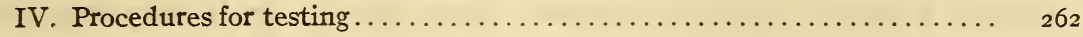

I. Procedure for sampling press cloth $\ldots \ldots \ldots \ldots \ldots \ldots \ldots \ldots{ }_{26} 6_{2}$

2. Procedure for analysis. . . . . . . . . . . . . . . . . . ${ }_{26} 6_{3}$

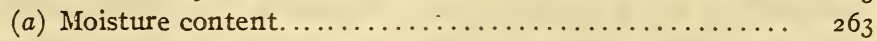

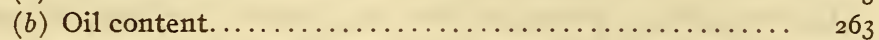

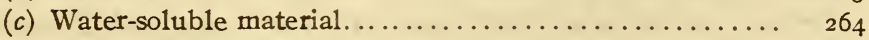

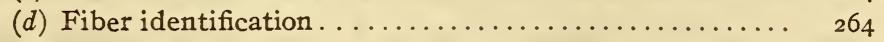

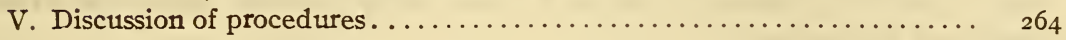

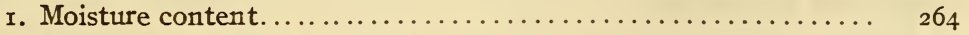

2. Oil content and water-soluble material................ ${ }_{2} 6_{5}$

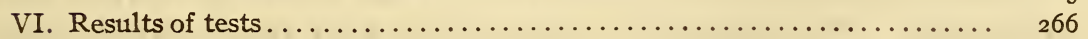

VII. Discussion of test results. . . . . . . . . . . . . . . . . . ${ }_{269}$

VIII. Recommended standards. . . . . . . . . . . . . . . . . . 276

\section{INTRODUCTION.}

\section{DESCRIPTION OF FABRIC.}

Press cloth is a heavy textile fabric made from various kinds of combinations or textile fibers, generally hair fibers. This cloth ranges up to a half inch in thickness and is usually made $I_{3}$ inches in width. Because of its great strength and porosity it is used to advantage principally in the presses of the oil-pressing industries. 


\section{USE OF FABRIC.}

The type of press most commonly used in this country in the production of cottonseed oil is the "steel box-frame hydraulic," which operates under a pressure against the ram of between 4,500 and $5,000 \mathrm{lbs}$./in. ${ }^{2}$ which in turn exerts a pressure of approximately $2,000 \mathrm{lbs}$. $/$ in. $^{2}$ on the cakes of material being pressed. Such a press consists of a series of horizontal steel plates about 14 inches wide by 34 inches long, set one above the other about 5 inches apart when the press is fully open. The plates are usually perforated or channeled and provided with closely fitting steel sides, so that the whole machine is really a series of steel boxes, without ends, piled one upon another, the lowest box resting upon a hydraulic piston. Above the top frame is a heavy iron plate fastened to the piston cylinder by four vertical rods, which serve as guides for the sliding frames.

With the press fully open-that is, with the piston at its lowest point - a measured charge of cooked meal is dropped from a subheater or holder upon a strip of press cloth in the cake former. This cake former is a steel block with a shallow groove, the size of a single press box. It is so constructed that after the meal has been run upon the press cloth and the two ends turned up over the charge, pressure can be applied from above or below and the cake, now covered with the cloth, except on its two sides, can be subjected to a preliminary squeeze to compact it into shape. After applying pressure for an instant, a sheet of steel the width of the groove is slid underneath the cake, which is then removed, cloth and all, from the cake former and pushed into the lowest frame of the press.

One after another the boxes of the press are thus charged until it is filled. The pressure is then applied to the hydraulic ram, forcing the frames upward each against the one above. The oil as it is squeezed from the cloths flows down over the sides of the press into a gallery around the bottom frame and out through troughs to the settling system.

\section{MATERIALS USED.}

The use to which this press-cloth material is put requires that the cloth have great strength and resiliency. This latter factor has made it desirable to use hair fibers to a large extent. Of these hairs camel hair seems to be used most, and human, horse, goat, mohair, and other hairs have been adopted with varying 
degrees of length and satisfaction of service. There is also some wool press cloth in use.

Previous to the war approximately 90 per cent of the camel's hair used by American press-cloth manufacturers was of the average grade of Russian camel hair and the remainder of Chinese camel hair. The war, however, prevented the importation of the Russian product and forced the American manufacturers of camel'shair press cloth to use the Chinese grade. Human hair is imported principally from China and Italy. Horse hair is a substitute for human hair, but is used in very limited quantities. Since it has not proved entirely satisfactory, goat hair is used in large quantities in the manufacture of the so-called gray wool press cloth, which contains ro to 50 per cent of goat hair.

\section{EXTENT OF USE.}

It was found that there are seven manufacturers of press cloth in the United States, and the total number of users varies from 575 to 650 . During the war there were over 800 users.

There are no available records of the number of pounds of press cloth in use, but the following estimation will give some idea of the extent of the industry. It is the experience of several of the larger cottonseed oil companies that it takes half a pound of press cloth for each ton of cotton seed worked. The amount varies with the different mills, some using more, some less, but half a pound may be considered a fair estimate. This year 3,000,000 tons of cotton seed will be crushed as against 4,500,000 tons in normal years. This year's press-cloth requirements will be about I,500,000 pounds for cottonseed oil mills. The amount of cloth used by other users for filtering and pressing would probably bring the total production of press cloth in this country per year for the past several years to about 3,500,000 pounds. This covers the crushing of copra, peanuts, palm kernels, charlock, mustard seed, and cocoa seed, as well as cotton seed and soya beans, and allows for that used for filtering purposes and in the confectionery trade.

\section{REASONS FOR INVESTIGATION.}

The ultimate cost of press cloth has always been of vital interest to millmen, and there is a vast range of price between the greatest and least cost. This variation results from a number of causesimproper handling, storage and cleaning of seeds, improper linting, separation, crushing, cooking, forming, or pressing of the meal all 
influence the wear and tear on the cloth. This interest in the service, and hence the cost of the press cloth, brought about the present investigation.

It is a well-known fact that all textile material is influenced in its properties by atmospheric moisture. The effect of the moisture on the weight is of interest in this connection. Various other textile branches have taken up the problem of moisture content in relation to weight. The silk industry, owing to the high cost per pound of its product, has formed a very comprehensive system of transacting sales on a standard moisture basis. It has been found very advantageous in this instance to set a standard moisture content and to buy on that basis. It is recognized that the material always contains some moisture under ordinary conditions, so that in transactions on a weight basis it was considered desirable to agree upon some standard moisture condition and to allow the percentage of moisture which was contained in the material at that condition. The silk interests are not alone in following out such a project, for definite standards have been fixed and adhered to more or less for transactions in wool, cotton, and various other fibers. It is true that this condition seems to be more prevalent in Europe than in the United States, and for that reason indications point to the fact that the American textile interests are somewhat negligent in not giving this factor more consideration. The United States Government in its specifications has taken cognizance of the influence of moisture on properties of cloth, and it is hoped that the textile trade will soon come to do so also.

The question of moisture content in its relation to selling is quite frequently misunderstood. In earlier days in the textile trade unscrupulous dealers, recognizing the ability of textile fibers to absorb moisture, took advantage of this by sprinkling or adding moisture in some way before the material was weighed. This practice fortunately has lessened, but there still remains the natural increase or decrease in weight due to changes in the humidity conditions of the atmosphere which are involved in transactions made where this atmospheric moisture is disregarded. Much of the opposition to moisture determinations developed from the fact that tests of this nature bring to buyers and sellers visions of large and expensive humidity regulating devices at their plants with the resulting additional expense. The test outlined later in this paper would not involve more than the slight additional trouble of packing and sending the sample to some easily accessible laboratory for tests for moisture content. Some press-cloth manu- 
facturers also look upon this as an infringement on their methods of manufacturing, but here again it can be stated that the manufacturer might pass his material through any series of wet processes and all the requirements would be met by adjusting the selling weight to that moisture content which would be permitted under normal conditions.

The percentage of oil content, while mostly a manufacturing problem, is also of primary importance to the buyer of press cloth. Hair fibers similar to wool, in their natural state, contain oil excreted at the roots of the hair fibers, and this often mixes with the perspiration and dirt to form a coating over the fiber. In the wool industry this is entirely removed by scouring to improve the feel and appearance of the fibers, to permit more efficient manufacturing processes, and to enable the fiber to take the dye. Some press-cloth fibers have also been scoured, but the expediency of scouring is open to question as to whether the additional expense caused by shrinkage in weight and labor involved is counterbalanced by the better qualities of the presscloth material. It must also be considered that the removal of all the natural oil causes the fibers to lack adhesiveness and increases waste or flyings. It is necessary then to add a certain amount of oil before the carding process. This is later removed in the case of wool manufacturing, so that the finished product is free from oil. In the case of hair press cloth, however, we find either the natural oil plus some of the additional oil or, if the fiber were previously scoured, this added oil alone remains. This condition involves a point of argument.

From the manufacturer's standpoint it is admittedly necessary to add oil to permit efficient manufacturing. It is also considered impracticable because of the additional expense involved in scouring the finished press cloth. Each manufacturer has different ideas as to what kind of oil and how much is needed.

According to the user's views, however, this oil is unnecessary in the work in which the press cloth is used, since the fabric is working with oil. He points out that since the oil is not essential in his work, and since press cloth is bought by weight, his interest demands that the amount of oil put into the fabric be minimized to eliminate the buying at press-cloth prices of a material which is of no value. As this oil is not actually detrimental except in extremely isolated cases, it would seem advantageous to ascertain and deduct from the gross weight the average percentage of oil in a shipment rather that to run the cloth through the scouring 
process. Rather than deduct the entire oil content it has been suggested that a certain permissible percentage of oil be fixed as standard which will allow the manufacturer to add such oil as is necessary for proper manufacturing and permit any excess to be subtracted from the weight of the shipment. It was for the purpose of having this oil standard as well as moisture content. standard fixed satisfactorily for manufacturer and user alike that this matter was brought to the attention of this bureau by one of the largest users of this material.

In a preliminary study of this problem a search through the various sources of information revealed very little data or information that would aid in its solution. It was found that various oil-pressing mills were testing or having tested, with varying results, samples of the cloths which were purchased. It was noted that several methods of tests were in vogue, and this led to confusion. Moisture content was determined as received at the testing house, and there was no attempt to have the test samples delivered in moisture-tight packages, so as to prevent changes in moisture condition between the weighing room and the test room. Determinations of moisture content, to be of any value whatever, should show the percentage of moisture present at the time of the weighing on which payment is based. The oil content with the exception of any slight evaporation would remain the same, so that the standardization of methods of determination would be all that is necessary to afford uniform results.

\section{PURPOSE OF INVESTIGATION.}

The purposes of the investigation were: (I) To formulate a method of sampling. (2) To formulate a method of procedure for ascertaining the percentage of oil in the sample. (3) To formulate a method of procedure for ascertaining the percentage of moisture in the sample. (4) To formulate a method of procedure for ascertaining the percentage of water-soluble material in the sample. (5) To ascertain by these methods the amounts of oil moisture, and water-soluble material in various commercial press cloths.

\section{PROCEDURES FOR TESTING.}

\section{PROCEDURE FOR SAMPLING PRESS CLOTH.}

Two samples at least 6 inches in length by the width of the material shall be taken from different parts of each roll at the time when the weight for which payment is made is taken. These 
samples shall be placed immediately in a moisture-tight container. Send to a testing laboratory for test.

\section{PROCEDURE FOR ANALYSIS.}

(a) Moisture ConTENT.- - ( I) 'Unseal the container and as quickly as possible take specimen ( 3 by 3 inches, approximately) and weigh to the nearest milligram (Wt. I). (2) Place in a drying oven which maintains a temperature of about $105^{\circ} \mathrm{C}$. for from four to six hours. (3) Place in desiccator until cool. Weigh. (4) Repeat 2 and 3 until weight checks within 0.5 of a milligram. Record last weight (Wt. 4).

Calculations-

Where

$$
\frac{(\text { Wt. I })-(\text { Wt. } 4)}{(\text { Wt. I })} \times 100=x
$$

$(x)=$ (percentage of moisture contained in the submitted sample). Then Where

$(x)-($ the standard permissible moisture content $)= \pm y$

$(y)=$ (per cent moisture content difference between the standard permissible moisture content and the amount of moisture actually in the shipment).

To reduce the weight of the roll to the standard permissible moisture content:

$\frac{\text { Wt. of roll }-(\mathrm{Wt} . \times x)}{\mathrm{IOO}-y} \times \mathrm{IOO}=\left\{\begin{array}{l}\text { Weight based on the material } \\ \text { containing standard permissible } \\ \text { moisture. }\end{array}\right.$

(b) OrL Content.-(I) Take a sample (3 by 3 inches, approximately) and weigh to the nearest milligram (Wt. I). (2) Extract with petroleum ether in a Soxhlet tube for five hours. (3) Evaporate the solvent until thoroughly dry. (4) Place the residue in a desiccator until cool. Weigh (Wt. 4). (5) Treat with ro cc of a 50 per cent solution of sodium hydroxide and $50 \mathrm{cc}$ of alcohol. (6) Boil the mixture for 30 minutes and allow to cool. (7) Place in a separator and add low boiling petroleum ether and shake. This dissolves out the mineral oil. (8) Draw the aqueous solution from the separator. (9) Repeat (7) and then (8) on the remainder after the aqueous solution is drawn off. (I0) Unite these two pertroleum ether mineral-oil solutions (9) and (7) and wash with alcohol. (I I) Evaporate off the petroleum ether. (I 2) Dry the residual mineral oil at $100^{\circ} \mathrm{C}$. (I3) Place in a desiccator until cool, then weigh (Wt. I3).

$26111^{\circ}-23-2$ 


\section{Calculations-}

$\frac{\text { (Wt. 4) }}{(\text { Wt. I })} \times 100=$ oil content (per cent).

$\frac{\text { (Wt. I3) }}{\text { (Wt. I ) }} \times 100=$ mineral oil content (per cent).

(Wt. 4) $-\left(\right.$ Wt. $\left.\mathrm{r}_{3}\right)=(\mathrm{Wt}$. of fatty oil).

$\frac{\text { (Wt. of fatty oil) }}{\text { (Wt. I) }} \times 100=$ fatty oil content (per cent).

(NoTE.-An average of two tests from each submitted sample shall be taken.)

(c) Water-Soluble Material.- ( I) Take the sample from which the oil is extracted by petroleum ether. (See Oil content (2).) (2) Wash with warm $\left(40^{\circ} \mathrm{C}\right.$.) distilled water. (3) Evaporate the extracts to dryness. (4) Cool the dry residue and weigh (Wt. 4).

\section{Calculation-}

$\frac{(W t .4)}{(\text { Wt. of sample (oil content I)) }} \times 100=\left\{\begin{array}{c}\text { water-soluble material } \\ \text { (per cent) } .\end{array}\right.$

(NoTE.-An average of two tests from each submitted sample shall be taken.)

(d) Fiber Identification.-Examine the extracted and cleaned fibers under the microscope and compare with authentic standard samples.

\section{DISCUSSION OF PROCEDURES.}

\section{MOISTURE CONTENT.}

Much of the argument against fixing standard percentages of oil and moisture contents arises from the difficulty of obtaining representative samples. One test of the variation in a single roll, the results of which were sent to the bureau by a user of this material, showed the following:

\begin{tabular}{|c|c|c|}
\hline & Moisture. & Oil. \\
\hline 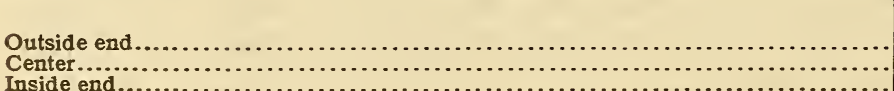 & $\begin{array}{r}\text { Per cent. } \\
8.40 \\
9.40 \\
9.70\end{array}$ & $\begin{array}{r}\text { Per cent. } \\
7.60 \\
7.66 \\
9.00\end{array}$ \\
\hline
\end{tabular}

These results show that the variation of moisture content between the center and the inside end is much smaller than the variation between the center and outside end. This is probably caused by the fact that the last turn from which the samples were taken to obtain test results as shown under outside end 
was more exposed to the air, thus permitting evaporation. This, together with the fact that the extreme inside end has little exposure to the air, seems to make it undesirable to cut the sample from either end. In order that the cost of sampling be not increased by reason of making parts of the roll unfit for use, it is suggested that, since the press cloth is to be cut into smaller pieces, samples should be taken after several of these pieces have been cut from the roll. Thus, if the press cloth is to be used in 36 -inch lengths, a sample could be taken after 3 yards have been taken from the roll under consideration and another after Io or I5 yards have been taken. The waste resulting in this way would be only that of the sample itself.

\section{OII CONTENT AND WATER-SOLUBLE MATERIAL.}

The procedures suggested are believed to be a thorough and accurate means for determining the oil and moisture content. Criticism of this method was offered by one of the manufacturers on the grounds that the natural grease or yolk contained in the walls of the fiber is extracted. This manufacturer suggested that the bureau use what he called "the usual method for testing for oil as followed by the trade and European conditioning houses." This method he stated as follows:

The material is tested for moisture first, and when the absolute dry weight is ascertained the sample, so arranged that no fibers can escape, is carefully washed in water at $120^{\circ} \mathrm{F}$. containing a small amount of good soap and a mild alkali (preferably ammonia) and then thoroughly rinsed and again dried to a constant weight. The percentage loss in weight during washing is the oil content.

A comparison of this suggested method with the one adopted by the bureau gave the following reșults:

\begin{tabular}{|c|c|c|c|c|}
\hline & \multicolumn{2}{|c|}{ Human hair. } & \multicolumn{2}{|c|}{ Camel hair. } \\
\hline & $\begin{array}{c}\text { Suggested } \\
\text { method. }\end{array}$ & $\begin{array}{l}\text { Bureau } \\
\text { method. }\end{array}$ & $\begin{array}{c}\text { Suggested } \\
\text { method. }\end{array}$ & $\begin{array}{l}\text { Bureau } \\
\text { method. }\end{array}$ \\
\hline $\begin{array}{l}\text { Fatty oil........ } \\
\text { Mineral oil... } \\
\text { Water-soluble }\end{array}$ & 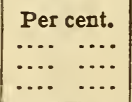 & $\begin{array}{rr}\text { Per cent. } \\
0.30 & 0.06 \\
2.27 & 2.28 \\
.63 & .49\end{array}$ & \begin{tabular}{|c|} 
Per cent. \\
\hdashline \\
\hdashline \\
\hdashline
\end{tabular} & $\begin{array}{r}\text { Per cent. } \\
0 \\
12.2 \\
5.4\end{array}$ \\
\hline Total.. & $2.95 \quad 2.70$ & $3.20 \quad 2.83$ & 17.4 & 17.6 \\
\hline
\end{tabular}

It is noted that these tests bring out the following points: The bureau method shows the content of fatty oil, mineral oil, and water-soluble material separately, while the suggested method gives the total of these. Although the difference between the 
totals as determined by the two methods is very small and may well be within the probable variation in different parts of the sample, the fact that the bureau method gives higher results seems to indicate that it more thoroughly extracts these substances from the material. The suggested method offers no indication as to whether this is made up of all water-soluble material or all oil or what type of oil. The suggested method requires more care in order to obtain accurate results, and there is always doubt lest some of the oil may remain unextracted, because much depends on the skill and experience of the operator.

\section{RESULTS OF TESTS.}

In order to ascertain the various percentages of foreign materials in commercial press cloths, 27 samples of the different types of press cloths were secured on which results were obtained as shown in Table $\mathrm{I}$.

TABLE 1.-Chemical and Microscopical Results.

\begin{tabular}{|c|c|c|c|c|c|c|c|c|c|c|}
\hline \multirow[b]{2}{*}{ No. } & \multirow[b]{2}{*}{$\begin{array}{l}\text { Mill } \\
\text { No. }\end{array}$} & \multirow[b]{2}{*}{$\begin{array}{c}\text { Mineral } \\
\text { oil. }\end{array}$} & \multirow[b]{2}{*}{$\begin{array}{l}\text { Fatty } \\
\text { oil. }\end{array}$} & \multirow[b]{2}{*}{$\begin{array}{l}\text { Total } \\
\text { oil. }\end{array}$} & \multicolumn{2}{|c|}{ Moisture content. ${ }^{1}$} & \multirow[b]{2}{*}{$\begin{array}{c}\text { Water } \\
\text { soluble. }\end{array}$} & \multirow{2}{*}{$\begin{array}{c}\text { Total }{ }^{2} \\
\text { foreign } \\
\text { ingredi- } \\
\text { ents. }\end{array}$} & \multirow{2}{*}{ Fiber analysis. } & \multirow{2}{*}{$\begin{array}{l}\text { Fiber } \\
\text { diam- } \\
\text { eter. }\end{array}$} \\
\hline & & & & & $\begin{array}{c}\text { (a) } \\
\text { Unes- } \\
\text { tracted. }\end{array}$ & $\frac{(\mathrm{b})}{\mathrm{Es}-}$ & & & & \\
\hline & $\begin{array}{l}1 \\
1 \\
2 \\
2 \\
3\end{array}$ & \begin{tabular}{|c} 
Per cent. \\
5.81 \\
.68 \\
1.70 \\
1.63 \\
3.18
\end{tabular} & $\begin{array}{r}\text { Per cent. } \\
1.81 \\
7.46 \\
.64 \\
.74 \\
2.87\end{array}$ & $\begin{array}{r}\text { Per cent. } \\
7.62 \\
8.14 \\
2.34 \\
2.37 \\
6.05\end{array}$ & $\begin{array}{r}\text { Per cent. } \\
12.79 \\
9.98 \\
12.73 \\
12.63 \\
11.86\end{array}$ & $\begin{array}{r}\text { Per cent. } \\
9.60 \\
8.19 \\
8.89 \\
9.57 \\
9.71\end{array}$ & $\begin{array}{r}\text { Per cent. } \\
5.91 \\
5.33 \\
.84 \\
1.14 \\
5.04\end{array}$ & $\begin{array}{c}\text { Per cent. } \\
26.32 \\
23.45 \\
15.91 \\
16.14 \\
22.95\end{array}$ & 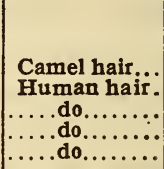 & \begin{tabular}{|r} 
Mi- \\
crons. $^{3}{ }^{3}$ \\
58 \\
118 \\
101 \\
72 \\
91
\end{tabular} \\
\hline & $\begin{array}{l}4 \\
5 \\
5\end{array}$ & $\begin{array}{r}\text { None. } \\
\text { Trace. } \\
.89\end{array}$ & $\begin{array}{l}7.62 \\
3.78 \\
3.77\end{array}$ & $\begin{array}{l}7.62 \\
3.78 \\
4.66\end{array}$ & $\begin{array}{l}11.23 \\
12.08 \\
12.55\end{array}$ & $\begin{array}{r}9.16 \\
8.66 \\
10.25\end{array}$ & $\begin{array}{l}3.69 \\
1.82 \\
1.19\end{array}$ & $\begin{array}{l}22.54 \\
17.68 \\
18.40\end{array}$ & $\begin{array}{l}\text { Camel hair.... } \\
\text { Mo ha ir or }\end{array}$ & $\begin{array}{r}110 \\
51 \\
36\end{array}$ \\
\hline $\begin{array}{r}9 \ldots \\
10 \ldots\end{array}$ & $\begin{array}{l}6 \\
6\end{array}$ & $\begin{array}{l}4.67 \\
\text { 3. } 31\end{array}$ & $\begin{array}{r}.37 \\
1.40\end{array}$ & $\begin{array}{l}5.04 \\
4.71\end{array}$ & $\begin{array}{l}12.05 \\
12.33\end{array}$ & $\begin{array}{r}7.56 \\
11.12\end{array}$ & $\begin{array}{l}4.41 \\
3.71\end{array}$ & $\begin{array}{l}21.50 \\
20.75\end{array}$ & $\begin{array}{l}\text { Camel hair.. } \\
\ldots . . . \text { do......... }\end{array}$ & $\begin{array}{r}128 \\
62\end{array}$ \\
\hline $\begin{array}{l}11 \ldots \\
12 \ldots \\
13 \ldots \\
14 \ldots \\
15 \ldots\end{array}$ & $\begin{array}{l}6 \\
6 \\
6 \\
6 \\
6\end{array}$ & $\begin{array}{l}2.41 \\
1.31 \\
1.38 \\
2.16 \\
4.20\end{array}$ & $\begin{array}{l}3.10 \\
3.83 \\
4.68 \\
3.23 \\
2.23\end{array}$ & $\begin{array}{l}5.51 \\
5.14 \\
6.06 \\
5.39 \\
6.53\end{array}$ & $\begin{array}{l}12.46 \\
13.04 \\
12.48 \\
12.68 \\
12.41\end{array}$ & $\begin{array}{l}7.93 \\
7.32 \\
9.71 \\
7.42 \\
7.28\end{array}$ & $\begin{array}{l}4.00 \\
1.61 \\
1.83 \\
1.68 \\
2.31\end{array}$ & $\begin{array}{l}21.97 \\
19.79 \\
20.37 \\
19.75 \\
21.15\end{array}$ & 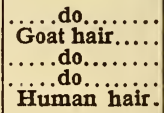 & $\begin{array}{r}52 \\
92 \\
101 \\
118 \\
101\end{array}$ \\
\hline $\begin{array}{l}16 . . \\
17 . . \\
18 . . \\
19 .\end{array}$ & $\begin{array}{l}6 \\
6 \\
4 \\
4 \\
4\end{array}$ & $\begin{array}{r}4.12 \\
3.76 \\
\text { None. } \\
\text { None. } \\
\text { None. }\end{array}$ & $\begin{array}{l}1.18 \\
1.35 \\
5.52 \\
6.92 \\
5.26\end{array}$ & $\begin{array}{l}5.30 \\
5.11 \\
5.52 \\
6.92 \\
5.26\end{array}$ & $\begin{array}{l}12.27 \\
12.13 \\
12.33 \\
11.55 \\
12.13\end{array}$ & $\begin{array}{r}9.74 \\
11.30 \\
10.81 \\
11.97 \\
11.27\end{array}$ & $\begin{array}{l}1.73 \\
5.09 \\
.97 \\
1.16 \\
4.57\end{array}$ & $\begin{array}{l}19.30 \\
22.33 \\
18.82 \\
19.63 \\
21.96\end{array}$ & $\begin{array}{c}\ldots . \text { do } \ldots . . . . . \\
\text { Mohair......... } \\
\text { C...do ........ } \\
\text { Camel hair... }\end{array}$ & $\begin{array}{l}92 \\
82 \\
46 \\
35 \\
52\end{array}$ \\
\hline $\begin{array}{l}21 . . \\
22 . \\
23 .\end{array}$ & $\begin{array}{l}4 \\
4 \\
4 \\
4\end{array}$ & $\begin{array}{l}\text { None. } \\
\text { None. } \\
\text { None. } \\
\text { None. }\end{array}$ & $\begin{array}{r}7.75 \\
10.90 \\
4.49 \\
6.41\end{array}$ & $\begin{array}{r}7.75 \\
10.90 \\
4.49 \\
6.41\end{array}$ & $\begin{array}{l}11.26 \\
11.11 \\
10.31 \\
10.96\end{array}$ & $\begin{array}{r}10.51 \\
9.79 \\
9.29 \\
10.58\end{array}$ & $\begin{array}{l}4.88 \\
5.01 \\
4.36 \\
3.70\end{array}$ & $\begin{array}{l}23.89 \\
27.02 \\
19.16 \\
21.07\end{array}$ & \begin{tabular}{l}
$\ldots \ldots d$ \\
\hdashline Hum \\
Hum
\end{tabular} & $\begin{array}{l}79 \\
52 \\
87\end{array}$ \\
\hline $\begin{array}{l}25 \ldots \ldots \ldots \\
26 \ldots \ldots \ldots \\
27 \ldots \ldots\end{array}$ & $\begin{array}{l}4 \\
4 \\
4\end{array}$ & $\begin{array}{l}\text { None. } \\
\text { None. } \\
\text { None. }\end{array}$ & $\begin{array}{l}5.34 \\
4.40 \\
6.71\end{array}$ & $\begin{array}{l}5.34 \\
4.40 \\
6.71\end{array}$ & $\begin{array}{l}10.86 \\
10.71 \\
11.41\end{array}$ & $\begin{array}{r}10.37 \\
9.37 \\
10.11\end{array}$ & $\begin{array}{l}2.84 \\
2.70 \\
2.54\end{array}$ & $\begin{array}{l}19.04 \\
17.84 \\
20.66\end{array}$ & $\begin{array}{l}\text { Camel hair... } \\
\text { Human hair. }\end{array}$ & $\begin{array}{l}36 \\
35 \\
66\end{array}$ \\
\hline Average. & & 1.53 & 4.21 & 5.74 & 11.86 & 9.54 & 3.11 & 20.72 & & \\
\hline
\end{tabular}

1 "Extracted" and "unextracted" refer to the condition of the fiber when the test was run, extracted meaning that the oil and water-soluble had been extracted.

2 Total oil, water-soluble, moisture (a).

${ }^{3} \mathrm{~A}$ micron is $0.00 \mathrm{r}$ of a millimeter. 
TABLE 2.-Averages of Different Mills.

\begin{tabular}{|c|c|c|c|c|c|c|c|}
\hline \multirow[b]{2}{*}{ Mill number. } & \multirow[b]{2}{*}{$\begin{array}{c}\text { Mineral } \\
\text { oil. }\end{array}$} & \multirow[b]{2}{*}{$\begin{array}{l}\text { Fatty } \\
\text { oil. }\end{array}$} & \multirow[b]{2}{*}{$\begin{array}{l}\text { Total } \\
\text { oil. }\end{array}$} & \multicolumn{2}{|c|}{ Moisture content. } & \multirow[b]{2}{*}{$\begin{array}{l}\text { Water- } \\
\text { soluble. }\end{array}$} & \multirow{2}{*}{$\begin{array}{l}\text { Total } \\
\text { foreign } \\
\text { ingre- } \\
\text { dients. }{ }^{1}\end{array}$} \\
\hline & & & & $\begin{array}{c}(a) \\
\text { Unex- } \\
\text { tracted. }\end{array}$ & $\begin{array}{l}\text { (b) } \\
\text { Extrac- } \\
\text { ted. }\end{array}$ & & \\
\hline 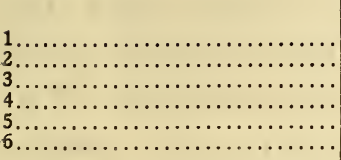 & $\begin{array}{r}\text { Per cent. } \\
\text { 3. } 24 \\
\text { 1. } 67 \\
\text { 3. } 18 \\
.0 \\
.45 \\
\text { 3. } 04\end{array}$ & $\begin{array}{r}\text { Per cent. } \\
4.64 \\
.69 \\
2.87 \\
6.48 \\
3.78 \\
2.38\end{array}$ & $\begin{array}{r}\text { Per cent. } \\
7.88 \\
2.36 \\
6.05 \\
6.48 \\
4.22 \\
5.41\end{array}$ & $\begin{array}{r}\text { Per cent. } \\
11.39 \\
12.68 \\
11.86 \\
11.26 \\
12.32 \\
12.43\end{array}$ & $\begin{array}{r}\text { Per cent. } \\
8.90 \\
9.23 \\
9.71 \\
10.29 \\
9.46 \\
8.82\end{array}$ & $\begin{array}{r}\text { Per cent. } \\
5.62 \\
.99 \\
5.04 \\
3.31 \\
1.51 \\
2.93\end{array}$ & $\begin{array}{r}\text { Per cent. } \\
24.89 \\
16.03 \\
22.95 \\
21.06 \\
18.04 \\
20.77\end{array}$ \\
\hline
\end{tabular}

1 Total oil, water-soluble, moisture (a).

TABLE 3.-Averages of Different Fibers.

\begin{tabular}{|c|c|c|c|c|c|}
\hline & \multirow[b]{2}{*}{$\begin{array}{c}\text { Total } \\
\text { oil. }\end{array}$} & \multicolumn{2}{|c|}{ Moisture content. } & \multirow[b]{2}{*}{$\begin{array}{l}\text { Water- } \\
\text { soluble. }\end{array}$} & \multirow{2}{*}{$\begin{array}{l}\text { Total } \\
\text { foreign } \\
\text { ingre- } \\
\text { dients.1 }\end{array}$} \\
\hline Fiber. & & $\begin{array}{c}\text { (a) } \\
\text { Uner- } \\
\text { tracted. }\end{array}$ & $\begin{array}{l}\text { (b) } \\
\text { Extrac- } \\
\text { ted. }\end{array}$ & & \\
\hline $\begin{array}{l}\text { Camel } \\
\text { Human } \\
\text { Goat. } \\
\text { Mohair } \\
\text { Monn. }\end{array}$ & \begin{tabular}{|r} 
Per cent. \\
6.03 \\
5.46 \\
5.53 \\
5.70
\end{tabular} & \begin{tabular}{|r} 
Per cent. \\
11.78 \\
11.70 \\
12.73 \\
12.14
\end{tabular} & $\begin{array}{r}\text { Per cent. } \\
9.62 \\
9.32 \\
8.15 \\
11.01\end{array}$ & $\begin{array}{r}\text { Per cent. } \\
3.99 \\
3.21 \\
1.71 \\
1.11\end{array}$ & $\begin{array}{r}\text { Per cent. } \\
21.80 \\
20.36 \\
19.97 \\
18.95\end{array}$ \\
\hline
\end{tabular}

1 Total oil, water-soluble, moisture (a).

TABLE 4.-Variations from Averages.

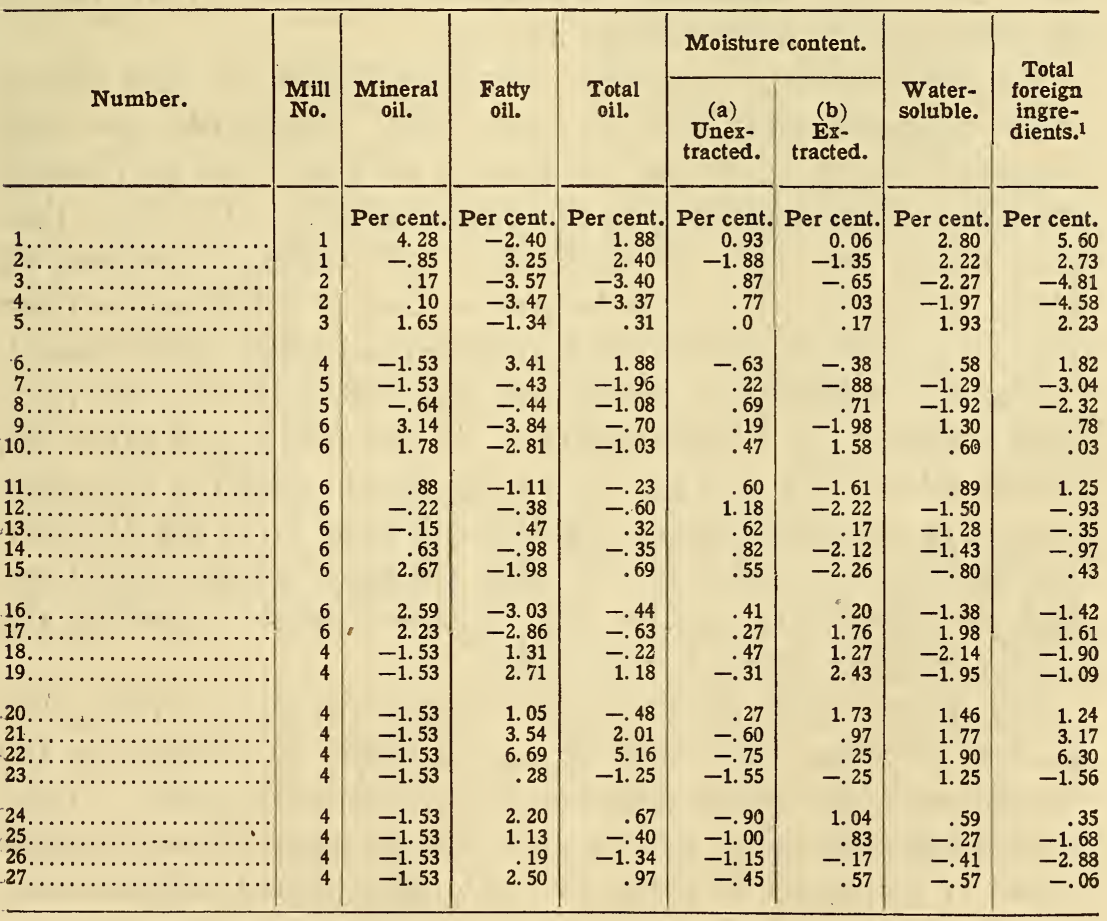

1 Total oil, water-soluble, moisture (a). 
The numbers from I to 27 were assigned consecutively as the samples were received. The method outlined above of obtaining oil content and water-soluble material was followed in these tests. In ascertaining moisture content, however, the purpose here was not to find how much moisture the samples contained as received, for there was no effort to seal the packages moisture tight, but to find just what percentage of moisture these samples would contain if subjected to a standard atmospheric condition of 65 per cent relative humidity at $70^{\circ} \mathrm{F}$. $\left(2 \mathrm{I} . \mathrm{I}^{\circ} \mathrm{C}\right.$.). The samples were accordingly conditioned thoroughly and weighed to obtain weight (I), the successive steps being in accordance with the suggested procedure. This test was duplicated on portions of the samples after extraction of oil and water-soluble material. The results obtained are given in Table $\mathrm{I}$.

No attempt was made to distinguish between the various oils in these fabrics because of the length of time required to carry out the tests and the complications resulting from the mixtures of fatty and mineral oils in most of the samples. There seems to be a general opinion that mineral oil is not particularly desirable, because of its probable effect on the oils which are pressed out. It is noted, however, by reference to Table 2 that four of the six mills use it in varying amounts.

The fatty oil was probably commercial olive oil, lard oil, or some vegetable wax, such as Japan wax. Obviously, the best procedure would be to use the kind of oil that is to go through the press, but a suggestion to this effect brought out the fact that press cloths are made for all kinds of oil-pressing industries, of which the cotton seed is the largest, so that if cottonseed oil was used on presses going into the cottonseed industries small quantities would generally be carried on the machines into the press cloth intended for other industries. In the pressing of other oils this would show up as a contamination, for the presence of cottonseed oil in the most minute quantity will show up in the Halphen test, and it is impossible to determine the exact amount of cottonseed oil mixed with another oil. This necessitates branding the oil as a mixture which is undesirable.

The water-soluble material here includes foreign materials, such as dust or other dirt naturally on the fiber, in addition to the substances which water dissolves out of the press cloth. "Total foreign ingredients" is a term used here to mean those materials added or contained in the press cloth other than the fiber itself; 
that is, the total oil, water-soluble material, and the moisture as shown in column (a) for unextracted samples.

In determining fiber by the microscopical method the specimens were compared with standard samples at the bureau and with samples obtained through the courtesy of the Smithsonian Institution from the National Zoological Park. The fiber diameter is given here to permit a comparison of the fineness of the individual fibers of the samples.

\section{DISCUSSION OF TEST RESULTS.}

In Figure I there is plotted the relation of the percentage of oil to the percentages of the various other additional materials. The percentage of oil is arranged according to ascending values. This graph shows that there is no regular relation between the oil content and the various other additional ingredients. This is interesting in that it is in direct contradiction with the theoretical argument advanced by several of the interested parties that the liquid content tended to remain a constant for this class of material; that is, that a direct relation existed between the oil and moisture contents. This is more graphically shown in Figure 2, where the moisture contents arranged according to the ascending values are plotted and connected. The corresponding values for the oil content show that no relation exists. The graphs shown in Figure 3 show similar features concerning camel hair and human hair, the figures of which were taken from Table I. Figures I, 2, and 3 illustrate the range of these results and show the need of fixing some standard whereby manufacturer and user are treated with equal fairness.

The distribution of the results obtained on press cloths composed of the various fibers is shown in Figure 4. This graphically illustrates Table 3. The oil contents and moisture show small deviation from the average. The low water-soluble content of mohair indicates that this was scoured before manufacture.

In Figure 5 there is shown a graphical comparison of the various percentages of the different mills as shown by the samples submitted. Mills 2 and 5 have the lowest total content of foreign ingredients. Mill 2 scours the fiber and adds generally less than 2 per cent of oil, so that there is offered a means of comparison of results gained with this method and the method which leaves the fiber unscoured. Comparing the highest total results with the lowest, the buyer is getting Ir.6 per cent more press cloth for a given weight for the latter. 


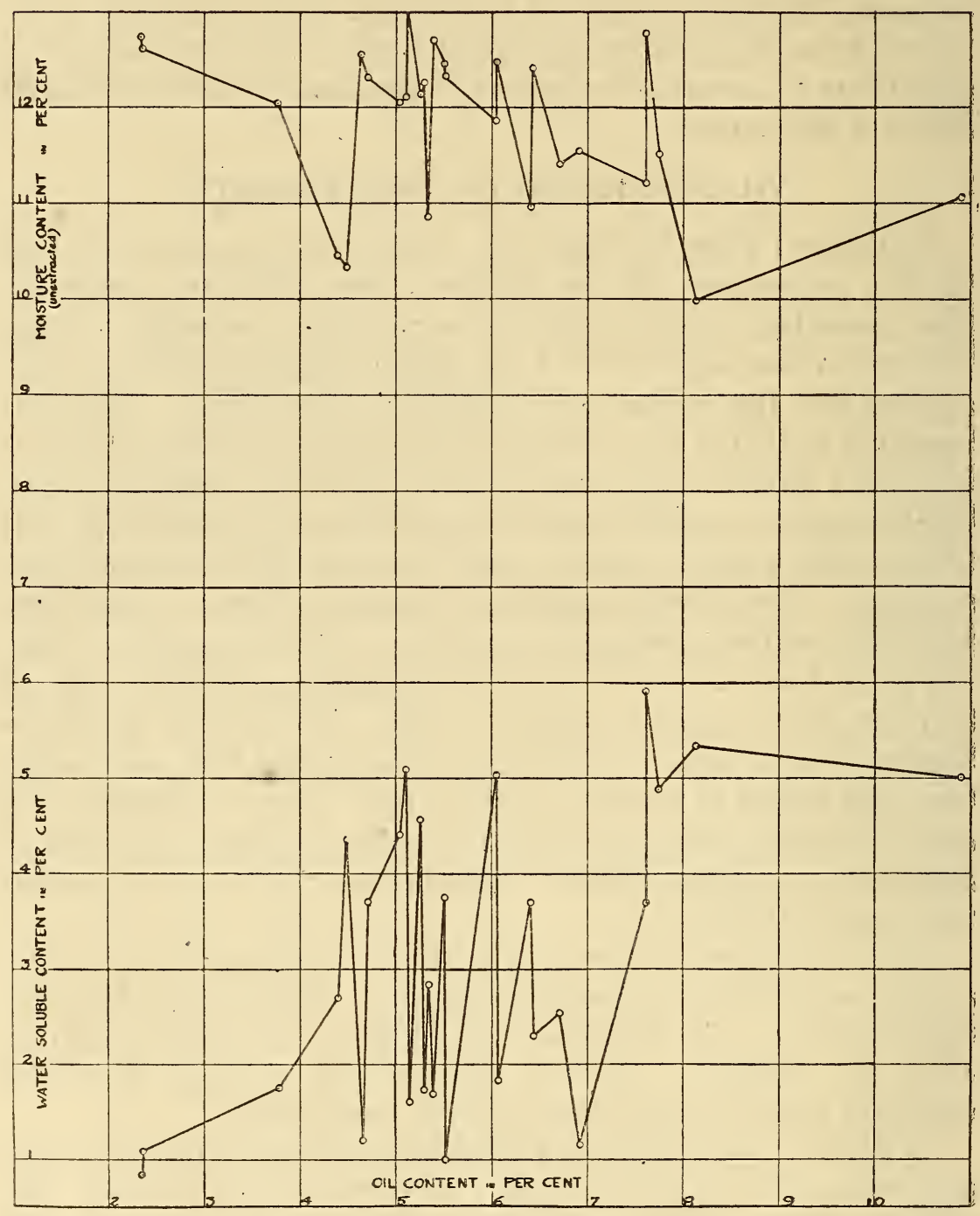

FIG. I.-Relation of oil content to moisture content and to water-soluble content. 


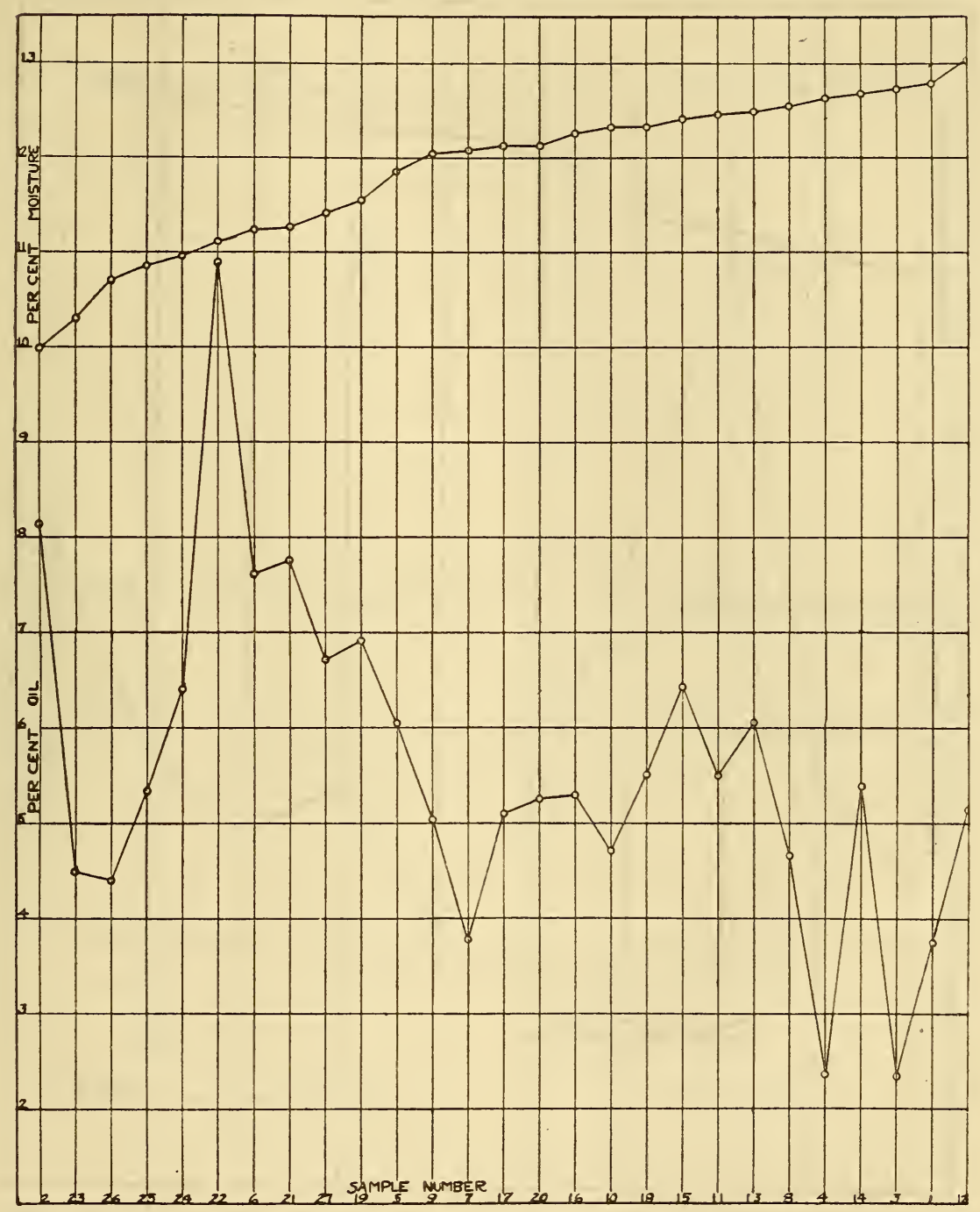

FIG. 2.-Relation of moisture content to oil content when moisture content is arranged according to ascending values. 


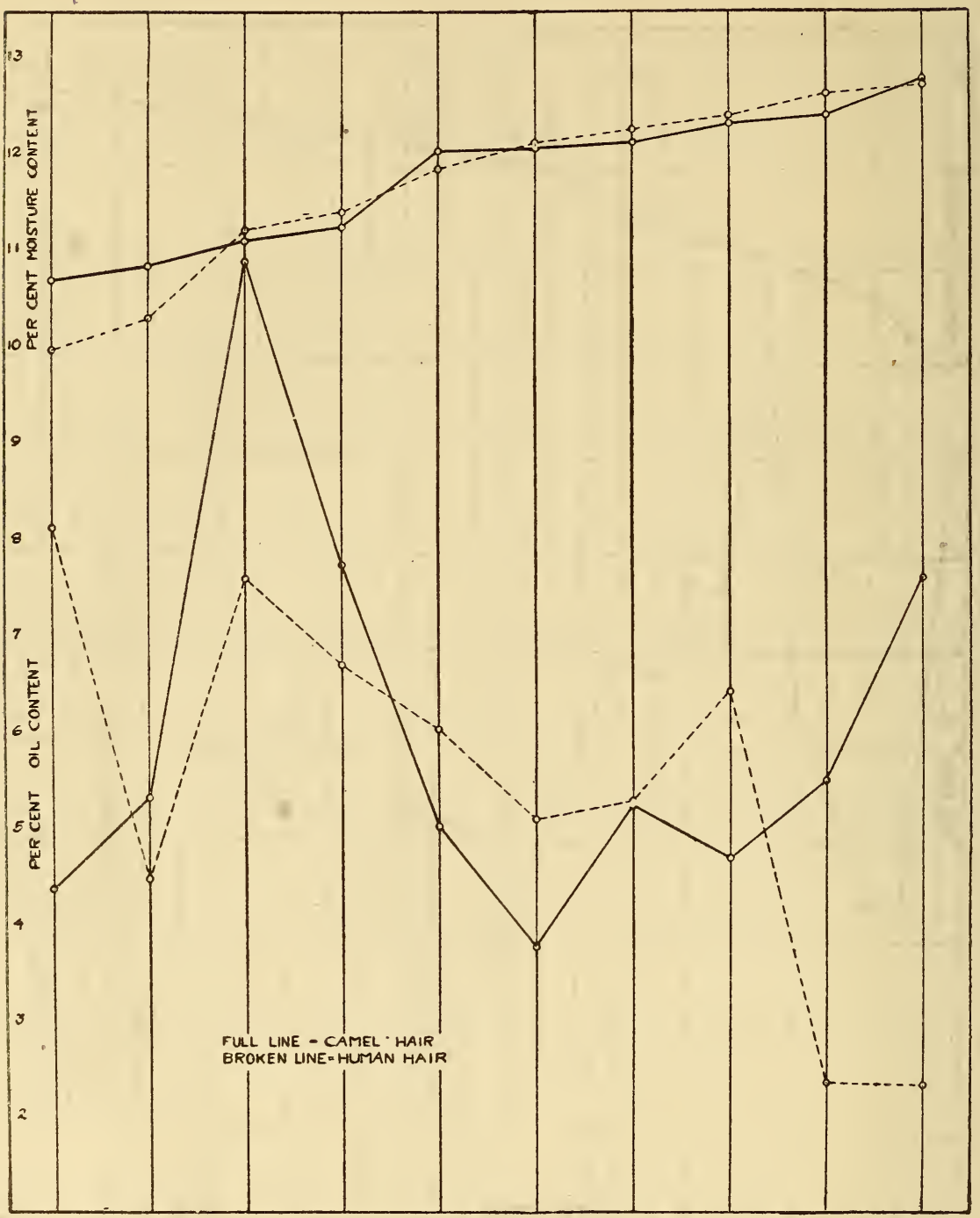

FIG. 3.-Comparison of camel hair and human hair in regard to oil and moisture content. Arranged according to ascending values of moisture content. 


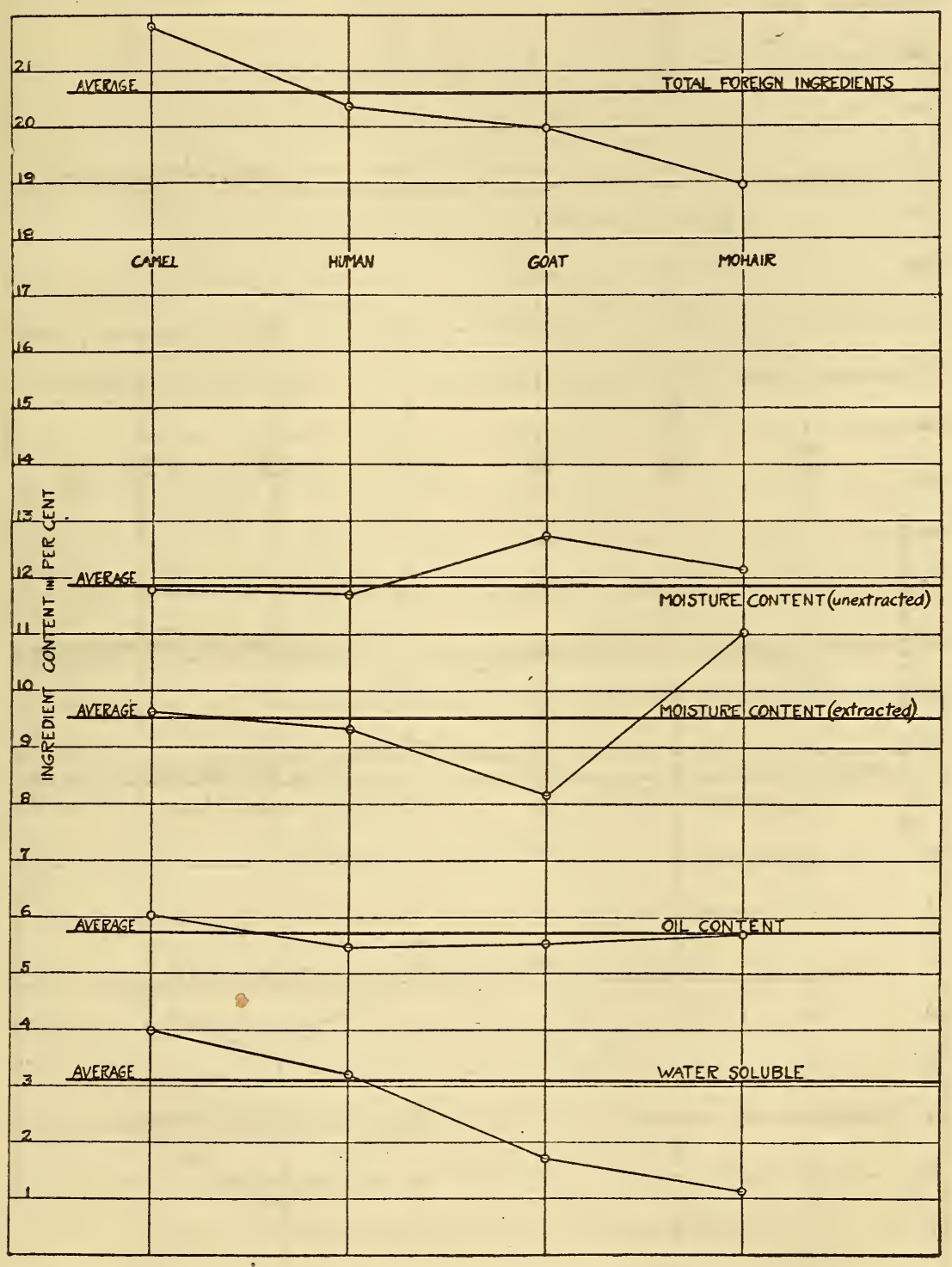

FIG. 4.-Comparison of press cloths in relation to their fiber composition. 


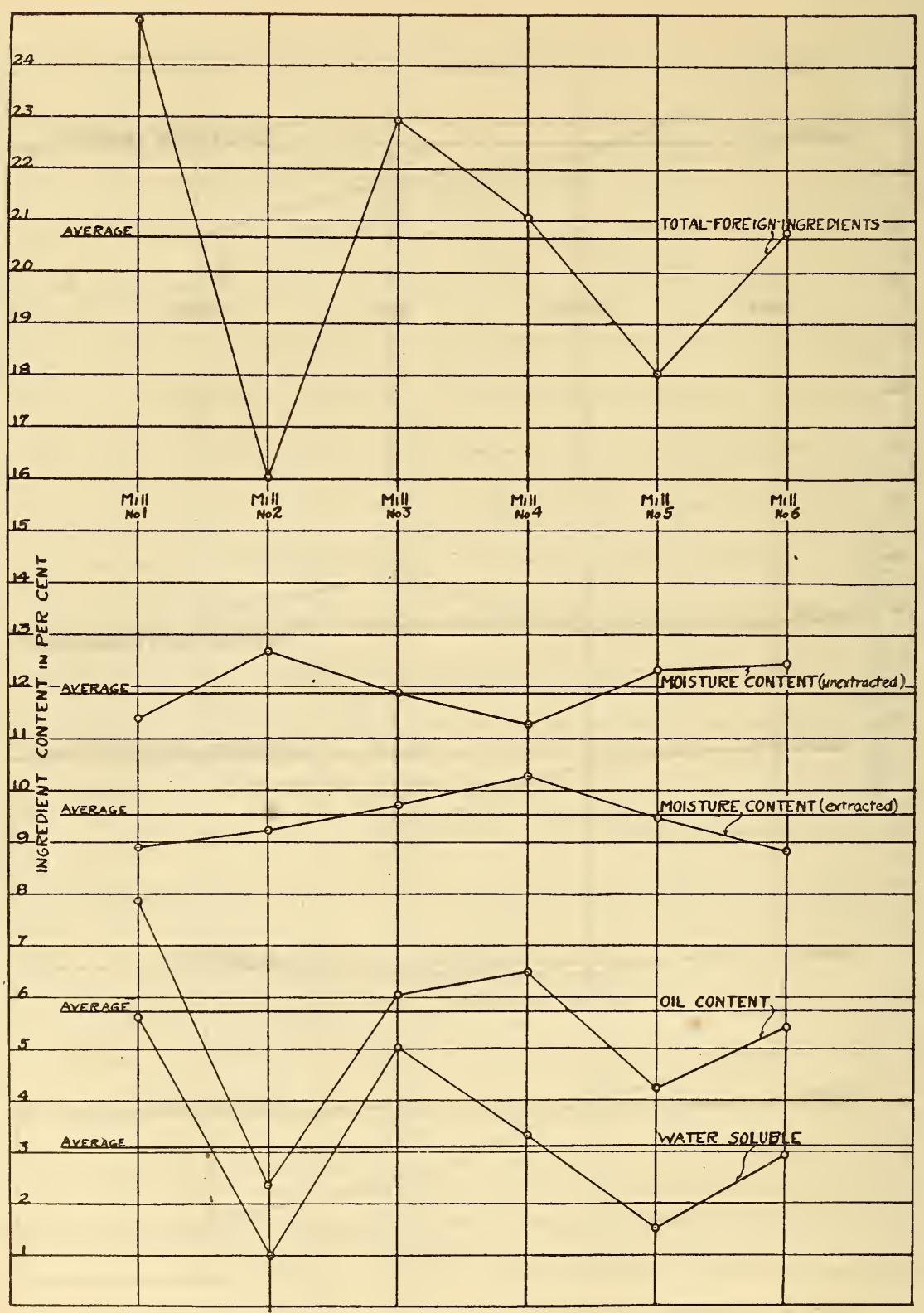

FIG. 5.-Comparison of the various percentages in cloths from the different mills. 
The distribution of the samples over the various percentages is shown in Figure 6. From this graph it will be noticed that the range of oil content is from 0.2 to 8 per cent, and the mode or point at which most samples fall is 5 per cent. For moisture

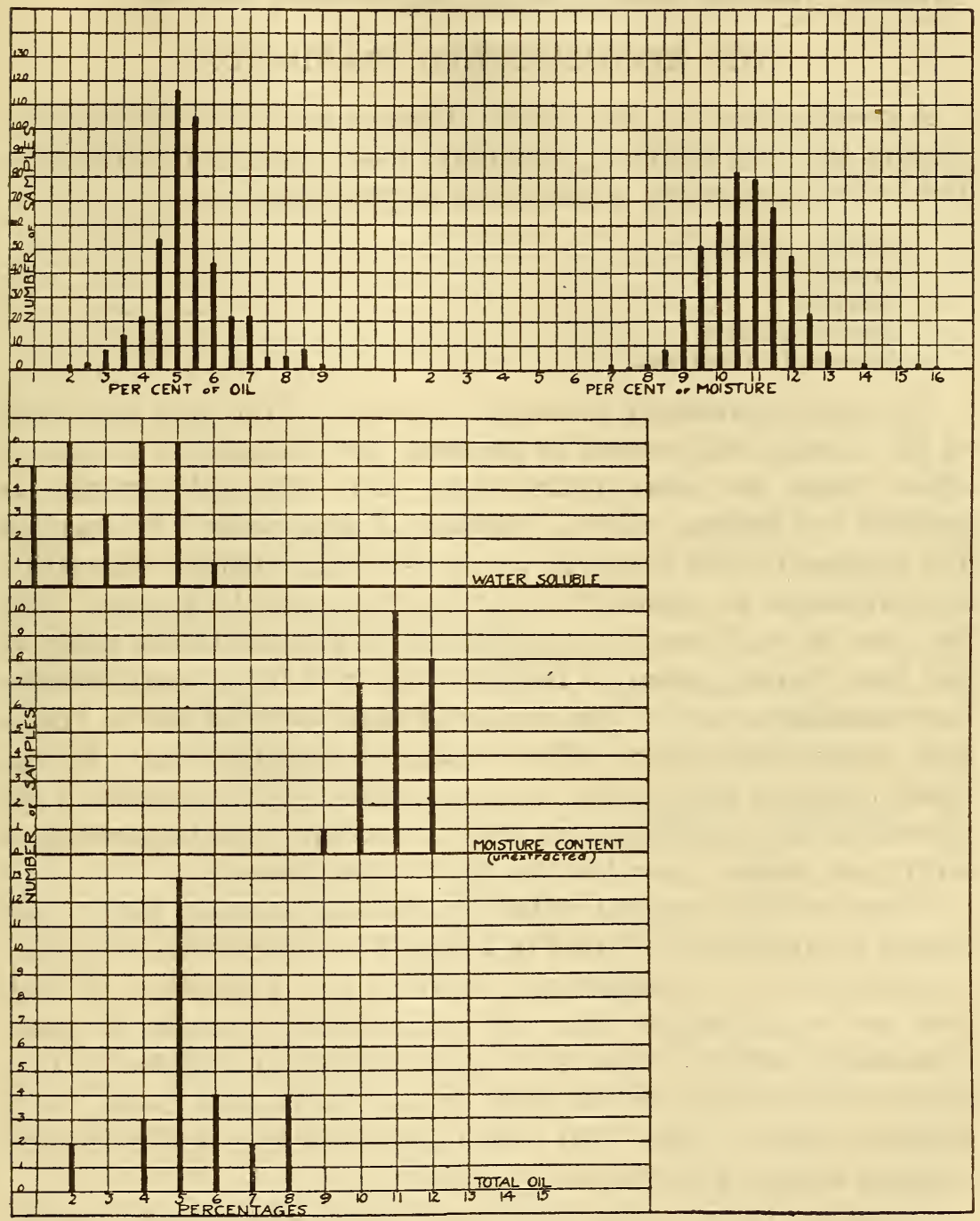

FIG. 6.-Distribution graph for the various percentages.

content the range is from 9 to 12 per cent and the mode i I per cent. For water-soluble material the range is from o. I to 6 per cent, well distributed.

From some data on over 400 samples submitted by one of the manufacturers it was found, as shown in Figure 6 above, that the range is from 0.2 to 8,2 per cent and the mode 5 per cent for oil: 
and the range 7 to 16 per cent, the mode I I per cent for moisture content. The greater range on moisture content is due to the fact that the adopted procedure was followed in this case. In the bureau results the standard humidity conditions lower the range. However, the results in these two graphs check very well.

\section{RECOMMENDED STANDARDS.}

A consideration of the results obtained leads to a logical conclusion that the following standards should be recommended for the buying and selling transactions of press cloth:

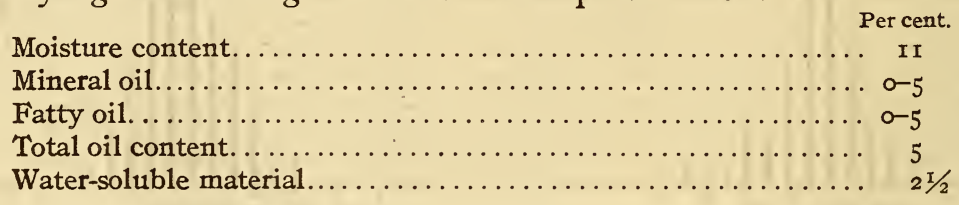

In regard to moisture content, it is shown in the data that most of the samples fall around II per cent, and though the average is above there are more under than over. The oil content, as pointed out before, raises a number of arguments. It was not the purpose of this investigation to ascertain whether mineral oil is detrimental as claimed by some of the press-cloth users. The fact that it was found in the products of four of the six mills, as has been shown, seems to indicate that it is being used whether objectionable or not. The standards recommended above, therefore, permit the use of either mineral or vegetable oil. By defining only the limit of the total oil content, parties entering the agreement may set figures for mineral and fatty oils in accordance with their wishes, provided this limit is not exceeded.

Water-soluble material influences the oil content, for it may absorb an amount of oil itself in addition to that needed for proper manipulation in manufacture. It is to the advantage of both user and manufacturer that the water-soluble material be small in amount, and it is doubtful if any material in addition to that naturally deposited on the fiber will be put in the cloth. It is believed that $2 \frac{1}{2}$ per cent will permit efficient manufacturing without requiring the scouring process.

In putting these standards into use it is suggested that suitable penalties be inserted for exceeding them. Consideration should be given the fact that there is an amount below which the cost of testing would exceed the value derived from enforcing these standards, so that there would be no necessity for testing some of the smaller shipments.

Washington, December 30, 1922. 